Ann. Génét. Sél. anim., I971, 3 (I), 59-70.

\title{
BLOOD GROUPS AND POLYMORPHIC PROTEINS IN CATTLE AND SWINE*
}

\author{
Bent LARSEN \\ Department of Physiology, Endocrinology and Bloodgrouping \\ The Royal Veterinary and Agricultural University, \\ I3, Bülowsvej, I870 Copenhagen V (Denmark)
}

\section{SUMMARY}

The well known blood group and polymorphic protein systems in cattle and pigs discovered and elucidated through immuno- and biochemical genetic studies are mentioned and the use of these systems in parentage control and as marker loci for improvement in animal breeding schemes is discussed.

The results from studies of genetic linkage among 10 blood group systems and 7 loci controlling protein polymorphism in cattle are presented and a close linkage of the bovine A blood group system to the haemoglobin types and a close genetic relationship of the $\alpha-, \beta-$, and $\mathbf{K}$-casein is found. Further a close relationship of the $J$ blood group system to the $\beta$-lactoglobulin types in cattle is discussed and the possibility of a loose linkage between the loci controlling transferrin and serum amylase polymorphism is mentioned.

Together with the linkage groups among cattle blood and protein polymorphisms, the linkage groups known in pigs and sheep are mentioned in relation to the possible future use of linkage to marker loci in animal breeding.

During the 30 years since systematic studies of blood groups in farm animals were initiated by means of isoimmune antibodies, the subject of immunogenetics and the more recent field of biochemical genetics have developed greatly and a number of gene controlled polymorphisms have been discovered and elucidated. In animal genetics it is of great interest to be able to identify genes at certain loci by means of relatively simple serological and biochemical methods. Also animal breeding programs have benefited from the discoveries of these polymorphisms. Identification of breeding animals, parentage control and in cattle the diagnosis of monozygotic twins and freemartins by means of blood grouping and

(*) Invited report presented in the Study Meeting of the European Association for Animal Production, Genetic Commission, Gödöllö, Hungary, August 27th, I97o. 
the more recently discovered polymorphic protein systems in many countries are incorporated into the breeding schemes. As a direct tool in selection programs, these polymorphisms have not proved successful so far. The hope that the immuno- of biochemically detectable polymorphisms should be of direct influence upon characters selected for in animal breeding has not been justified by results which were of significant value in selection programs for large farm animals. This however, may not mean that polymorphic systems will not be of any further value for animal breeding in the future. Thus analyses of the data on blood groups and polymorphic protein systems have revealed evidence for the first linkage groups within some of the polymorphic systems known to-day in farm animals. Also the great expansion of the number of known polymorphic systems, in particular polymorphic enzymes, going on at the moment may contribute to mapping out the chromosomes which in turn may result in the discovery of linkage of serologically or biochemically detectable marker locito characters, which it is of value either to remove or preserve in our domestic animals.

Before presenting some of the studies going on in this field I shall mention some of the polymorphic systems known in cattle and pigs.

\section{BLOOD GROUP SYSTEMS IN CATTLE AND SWINE}

The blood group factors or red cell antigens are identified by means of specific antisera or so-called blood type reagents, mainly prepared from isoimmune antisera. The formation of antibodies against the ted cell antigens is achieved by planned series of immunizations, and from the resulting antisera, specific reagents are prepared by appropriate antigen-antibody absorptions and tests for unity (NEIMANN-SORENSEN, I958).

The technique employed in the typing procedure for red cell antigens depends on the nature of the antibodies formed and the animal species to be typed. As indicated below the haemolytic test is exclusively used for the typing of cattle red cells, while three different test methods may be employed for swine (ANDRESEN, Ig63; HoJNý and HRAdECKÝ, Ig68).

\begin{tabular}{l|c|c|c}
\hline \hline & $\begin{array}{c}\text { Haemolytic } \\
\text { test }\end{array}$ & $\begin{array}{c}\text { Direct } \\
\text { agglutination }\end{array}$ & $\begin{array}{c}\text { Indirect } \\
\text { agglutination }\end{array}$ \\
\hline $\begin{array}{l}\text { Cattle } \\
\text { Pigs }\end{array}$ & $\begin{array}{c}+ \\
+\end{array}$ & + & + \\
Horse & $\begin{array}{c}+ \\
\text { Sheep }\end{array}$ & + & \\
\hline \hline
\end{tabular}

The term blood group system denotes a genetic system controlling the inheritance of one or more blood group factors. In table I the well known blood group systems in cattle and pigs and the factors they control are listed (see SToRMONT I962, ANDRESEN I963, HoJNÝ et al., I966). In cattle I2 systems are inter- 
nationally recognized and in pigs $I_{5}$ systems have been described. As it appears from the table, the number of factors belonging to the various systems range from one to approximately 30. With the exception of the Oc substance of cattle and the closely serologically related $O$ of pigs and $r(O)$ in sheep which appear as recessive characters (STORMONT, I95I; SPRAGUE, I958), the blood group factors known to-day in farm animals are inherited as dominants to their absence. For the systems where only a single factor is known this implies that two alleles can be recognized, e.g. the allele giving rise to the blood group factor in question and the so-called " silent " allele "-" (das), not forming a known antigen on the red cells. This type of system is called " open " in contrast to a " closed " system

TABLE I

The well-known blood group systems in cattle and pigs

TABLEAU I

Les groupes sanguins bien connus chez le bouf et le porc

\begin{tabular}{|c|c|c|c|}
\hline System & Number of factors & \multicolumn{2}{|c|}{ Number of alleles } \\
\hline \multicolumn{2}{|c|}{ Cattle } & & \\
\hline $\begin{array}{l}\mathrm{A} \\
\mathrm{B} \\
\mathrm{C} \\
\mathrm{FV} \\
\mathrm{J}^{*} \\
\mathrm{~L} \\
\mathrm{M} \\
\mathrm{SU} \\
\mathrm{Z} \\
\mathrm{R}^{\prime} \mathrm{S}^{\prime} \\
\mathrm{T}^{\prime} \\
\mathrm{N}^{\prime}\end{array}$ & $\begin{array}{r}>4 \\
>30 \\
\text { IO } \\
4 \\
\text { I } \\
\text { I } \\
3 \\
>6 \\
2 \\
2 \\
2 \\
I \\
\text { I }\end{array}$ & $\begin{array}{r}>8 \\
>200 \\
>\quad 50 \\
3 \\
2 \\
2 \\
3 \\
>10 \\
3 \\
2 \\
2 \\
2\end{array}$ & $\begin{array}{r}\text { open } \\
\text { open } \\
\text { open } \\
\text { closed } \\
\text { open } \\
\text { open } \\
\text { open } \\
\text { open } \\
\text { open } \\
\text { closed } \\
\text { open } \\
\text { open }\end{array}$ \\
\hline \multicolumn{2}{|c|}{ Pigs } & & \\
\hline $\begin{array}{l}A^{*} \text { ) } \\
B \\
C \\
D \\
\text { D } \\
\text { F } \\
\text { G } \\
\text { H } \\
\text { I } \\
\text { C } \\
\text { K } \\
\text { L } \\
M \\
\text { N } \\
O\end{array}$ & $\begin{array}{r}\mathbf{I} \\
2 \\
\mathbf{I} \\
2 \\
<.8 \\
2 \\
2 \\
3 \\
2 \\
2 \\
2 \\
5 \\
\text { I I } \\
>4 \\
3 \\
2\end{array}$ & $\begin{array}{r}2 \\
2 \\
2 \\
2 \\
> \\
8 \\
2 \\
2 \\
5 \\
2 \\
3 \\
5 \\
>6 \\
>8 \\
3 \\
2\end{array}$ & $\begin{array}{c}\text { open } \\
\text { closed } \\
\text { open } \\
\text { closed } \\
\text { closed } \\
\text { closed } \\
\text { closed } \\
\text { open } \\
\text { closed } \\
\text { open } \\
\text { open } \\
\text { closed } \\
\text { open } \\
\text { closed } \\
\text { closed }\end{array}$ \\
\hline
\end{tabular}

*) The Oc and O not counted. 
where the silent allele is not found. Thus the systems comprising more than one factor may form "closed" or "open" genetic systems controlling a number of multiple alleles. As indicated in table I the cattle R'S' system appears as a two allele closed system and in domestic cattle of Bos taurus origin the FV appears as a three allele closed system. In the more complex systems, such as the bovine B system, a number of alleles each of which controls the presence of one or more blood group factors, the so-called " phenogroups ", and the ,-, " gene are known. With rare exceptions these phenogroups are transmitted from parents to offspring as units.

In pigs the blood group factors tend to form closed systems more frequently than in cattle and other animal species. As indicated in table I six systems are recognized as two allele and three as multiple allelic closed systems.

\section{POLYMORPHIC PROTEIN SYSTEMS IN CATTLE AND SWINE}

Not only on the red cells but also on the leucocytes and blood platelets antigenic factors are present and the study of these has more recently been taken up in farm animals. However, also proteins and enzymes in the blood, milk and other body fluids exhibit gene controlled variations, some of which can be detected by serological methods, for instance by means of inhibition tests or immunodiffusion. The majority of the polymorphic protein systems known in farm animals to-day have, however, been detected by electrophoresis in a supporting medium of starch gel as introduced by SMrTHIEs in 1955. By electrophoresis in starch gels, which are prepared by heating a suspension of partially hydrolysed starch in a suitable buffer, the separation of the amphoteric protein molecules takes place on the basis of differences in charge and in molecular size. After completion of electrophoresis the gel may be stained or incubated in order to identify the components of the protein under study.

In table 2 a number of polymorphic protein systems which have been studied in cattle and pigs are indicated (for ref. see AschafFENBURG, I968, and HESseiHOLT, I969). Like the blood group factors, the components of the polymorphic proteins are controlled by genes dominant to their absence. To each other the alleles are non-dominant, which is referred to as codominance. Because a silent allele is not present in any of the systems indicated in table 2 , the genotype can be established directly from the phenotype.

The polymorphisms observed by starch gel electrophoresis are due to variation in the amino acid sequence in the polypeptide chains, and in recent years much work has been devoted to studies on proteins at the molecular level to provide a chemical basis for the variation exhibited by polymorphic proteins. Thus it has been shown that the difference between the bovine haemoglobin components $A$ and $B$ is due to the $\beta$-polypeptide chain of the haemoglobin molecule, where one glycine and two lysine residues in the $\beta^{\mathrm{A}}$ chain have been replaced in the $\beta^{\mathbf{B}}$ chain by one serine, one histidine and one aspartic acid residue (Huisman, I966). Also the polymorphic proteins of the cow's milk have been subjected to physicochemical and structural studies and the nature of the chemical differences between 
TABLE 2

Some of the polymorphic protein systems in cattle and pigs which have been studied by means of starch gel electrophoresis

TABLEAU 2

Quelques-uns des systèmes polymorphiques protéiniques du bouf et du porc étudiés par électrophorèse sur gel d'amidon

\begin{tabular}{|c|c|c|c|}
\hline \multirow{2}{*}{ Protein } & \multirow{2}{*}{ Locus symbol } & \multicolumn{2}{|c|}{ Number of alleles in } \\
\hline & & cattle & pigs \\
\hline \multicolumn{4}{|l|}{ In red cells } \\
\hline Haemoglobin & $\mathrm{Hb}$ & 4 & \\
\hline $\begin{array}{l}\text { Carbonic anhydrase } \\
6 \text { phosphogluconate-dehy- }\end{array}$ & $\mathrm{Ca}$ & 2 & 2 \\
\hline drogenase & 6-PGD & & 2 \\
\hline \multicolumn{4}{|l|}{ In serum } \\
\hline Transferrin & $\mathrm{Tf}$ & Io & 4 \\
\hline Amylase & Am & 4 & 4 \\
\hline Albumin & $\mathrm{Alb}$ & 6 & 3 \\
\hline Postalbumin & $\mathrm{Pa}$ & 2 & \\
\hline Prealbumin & Pra & & 2 \\
\hline Ceruloplasmin & $\mathrm{Cp}$ & 3 & 2 \\
\hline Hemopexin & $\mathrm{Hpx}$ & & 6 \\
\hline \multicolumn{4}{|l|}{ In milk } \\
\hline$\alpha$-lactalbumin & $\alpha-\mathrm{L} a$ & 2 & \\
\hline$\beta$-lactoglobulin & $\beta-\mathrm{Lg}$ & 4 & \\
\hline$\alpha_{s 1}-$ casein & $\alpha_{s 1}-C_{n}$ & 4 & 2 \\
\hline$\beta$-casein & $\beta-\operatorname{Cn}$ & 5 & 3 \\
\hline$x$-casein & $x-\mathrm{Cn}$ & 2 & \\
\hline$\gamma$-casein & $\gamma-\mathrm{Cn}$ & 2 & \\
\hline
\end{tabular}

the $\beta$-lactoglobulin $A$ and $B$ components was found to be due to two aspartic acid and two valine residues in the $\beta$-I $\mathrm{g}^{\mathrm{A}}$ being substituted by two glycine and two alanine residues in the $\beta-\mathrm{Lg}^{\mathrm{B}}$ component (GoRdoN et al., I96r; PIEZ et al., I96r). Such studies are under way also for the casein polymorphisms of cow's milk.

\section{APPLICATIONS OF BLOOD GROUP AND POLYMORPHIC PROTEIN SYSTEMS}

During the last Io to I5 years the blood groups and some of the polymorphic protein systems have been used in many countries for the identification of breeding animals, in parentage control and for cattle in the diagnosis of twins. This application has been and is still of great value for the breeding schemes of large farm animals since it is the only way to keep the necessary standard of the pedigree records and to make sure that progeny tests really are made with offspring from the parents whose ability is to be judged. Also in experiments with cattle 
twins it is valuable to be able to verify the morphological diagnosis of zygosity by tests for blood groups and polymorphic proteins.

The data on blood groups accumulated from investigations of this kind have first of all been used for the identification of the alleles present in the systems of the various breeds and for the characterization of the breeds by means of the frequencies of the polymorphic components. Since only systems showing variation are of value, these studies have contributed greatly to the knowledge about the usefulness of the various polymorphic systems for genetic studies within a given breed. Thus for example in Danish Landrace pigs the B, C and $\mathrm{O}$ blood group systems are useless because no variation occurs and the same is the case for the bovine haemoglobin system in Holstein Friesian cattle and many other domesticated cattle breeds.

Besides comparative and population genetic studies a number of investigations have been devoted to elucidating the possible relationship of loci controlling blood groups and polymorphic proteins to characters of economic importance for animal production. The studies in this field have been greatly stimulated by the pioner work of BRIIES and coworkers in chickens (BRILES and ALLAN, I96I), where heterozygosity at the B locus was observed to be related to superiority in viability and egg production. Thus a number of studies on the relation of the well known blood group systems and some of the polymorphic protein loci to productive characters have been carried out in cattle and pigs, indicating that some of these marker loci may be associated with production ability (MITSCHERLICH et al., I959; NEIMANN-SORENSEN and ROBERTSON, I96I; RENDEL, I96I; JAMIESON and ROBERTSON, I967; BRUM et $a l$., I968; JENSEN et $a l .$, I968). In particular certain alleles at the bovine B blood group locus have repeatedly been found to be related to milk and butterfat production, but also an effect of other loci has been observed.

SmiтH (I967) has described the conditions under which the use ot specific marker loci in selection programs may be of value. He points out that the value of marker genes depends on the amounts of the total genetic variation controlled by a marker locus in relation to the heritability of the character under study, and also to the form of selection practised. He concludes that for characters with high heritability and when normal selection is effective only little may be gained by including marker loci. However, for characters with low heritability or when indirect selection on relatives must be used, then the additional information obtained by marker loci may add significantly to the possible rate of improvement.

The possible effects of marker loci in relation to production so far disclosed in farm animals are small and without further studies may not be used in improvement schemes. Apart from serum amylases, however, polymorphic enzymes have so far not been included as marker loci in studies in relation to productive traits. With the rapid development in the discoveries of gene controlled variation in various enzymes, some of which play an important role in the animal body, it is, therefore, still possible that valuable relations between these marker loci and the quantity or quality of animal products may be found.

The increase in the number of known loci showing gene controlled variation. has more recently focused attention on the possibility of genetic linkage among 


\begin{tabular}{|c|c|c|c|}
\hline \multicolumn{4}{|c|}{$\infty$} \\
\hline 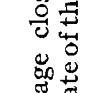 & 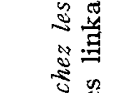 & $U$ & $\stackrel{\infty}{?}$ \\
\hline 寻罟 & 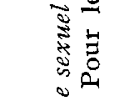 & 点 & $m \stackrel{m}{m} \stackrel{m}{?}$ \\
\hline 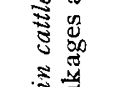 & 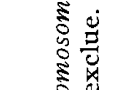 & $\curvearrowleft$ & के \\
\hline 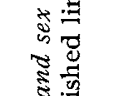 & 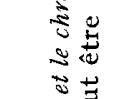 & た & 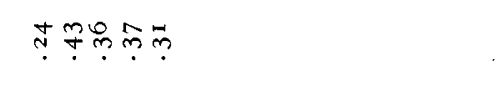 \\
\hline 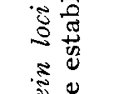 & 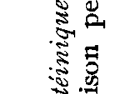 & $s$ & ติษษ ๆ \\
\hline 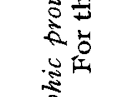 & है & 量 & 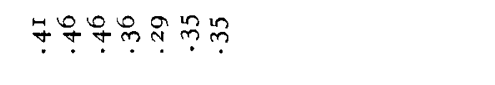 \\
\hline हैं & है & $\mathbf{N}$ & ตेํํำํํํํํำ \\
\hline 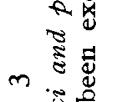 & 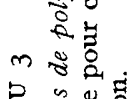 & is & 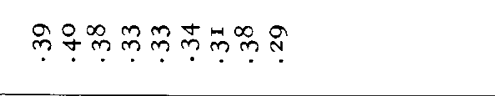 \\
\hline 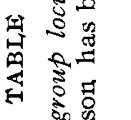 & 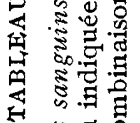 & 届 & 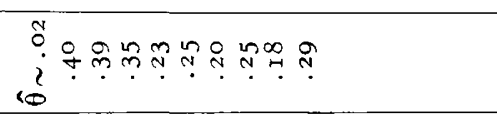 \\
\hline 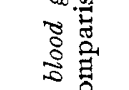 & 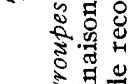 & 屿 & 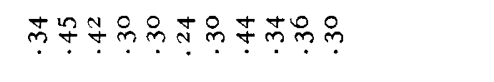 \\
\hline 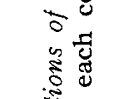 & 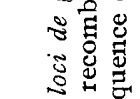 & 䒧 & 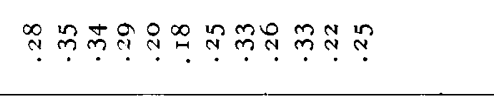 \\
\hline 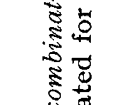 & 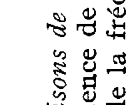 & 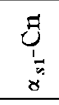 & 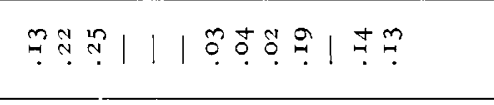 \\
\hline 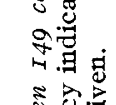 & 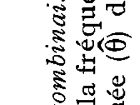 & f્d & F⿻ำ \\
\hline 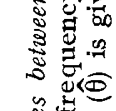 & 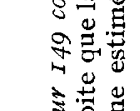 & $\underset{\dot{x}}{5}$ & 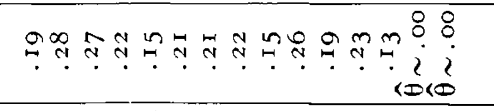 \\
\hline 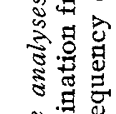 & 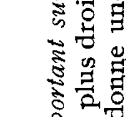 & 足 & 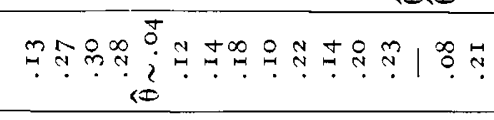 \\
\hline 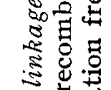 & 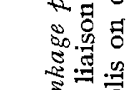 & ڤ̆丶 & 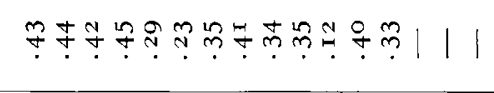 \\
\hline 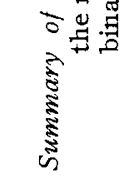 & 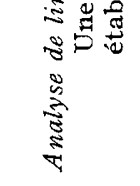 & & 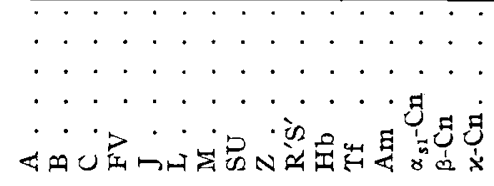 \\
\hline
\end{tabular}


the immuno- or biochemically detectable systems in farm animals. Analyses of this kind as well as those mentioned above have been greatly facilitated by computers now available in many laboratories and because of the development of computer programs which can handle the problems to be studied.

Using the data on bovine blood groups and polymorphic proteins which have been accumulated during some years we have recently completed an analysis for genetic linkage among ro blood group systems and 7 polymorphic protein systems, the results of which are summarized in table 3. The details about the methods applied and the data have been published elsewhere (LARSEN, I970). The figures in table 3 indicate the recombination frequencies for which linkage can

TABLE 4

Summary of families showing linkage relations of blood group and polymorphic protein systems in cattle.

The families are grouped according to the most probable phase of the sire.

\section{TABLEAU 4}

Relations familiales de linkage entre groupes sanguins et systèmes polymorphiques protéiniques chez les Bovins.

Les familles sont groupées selon la phase du père la plus probable.

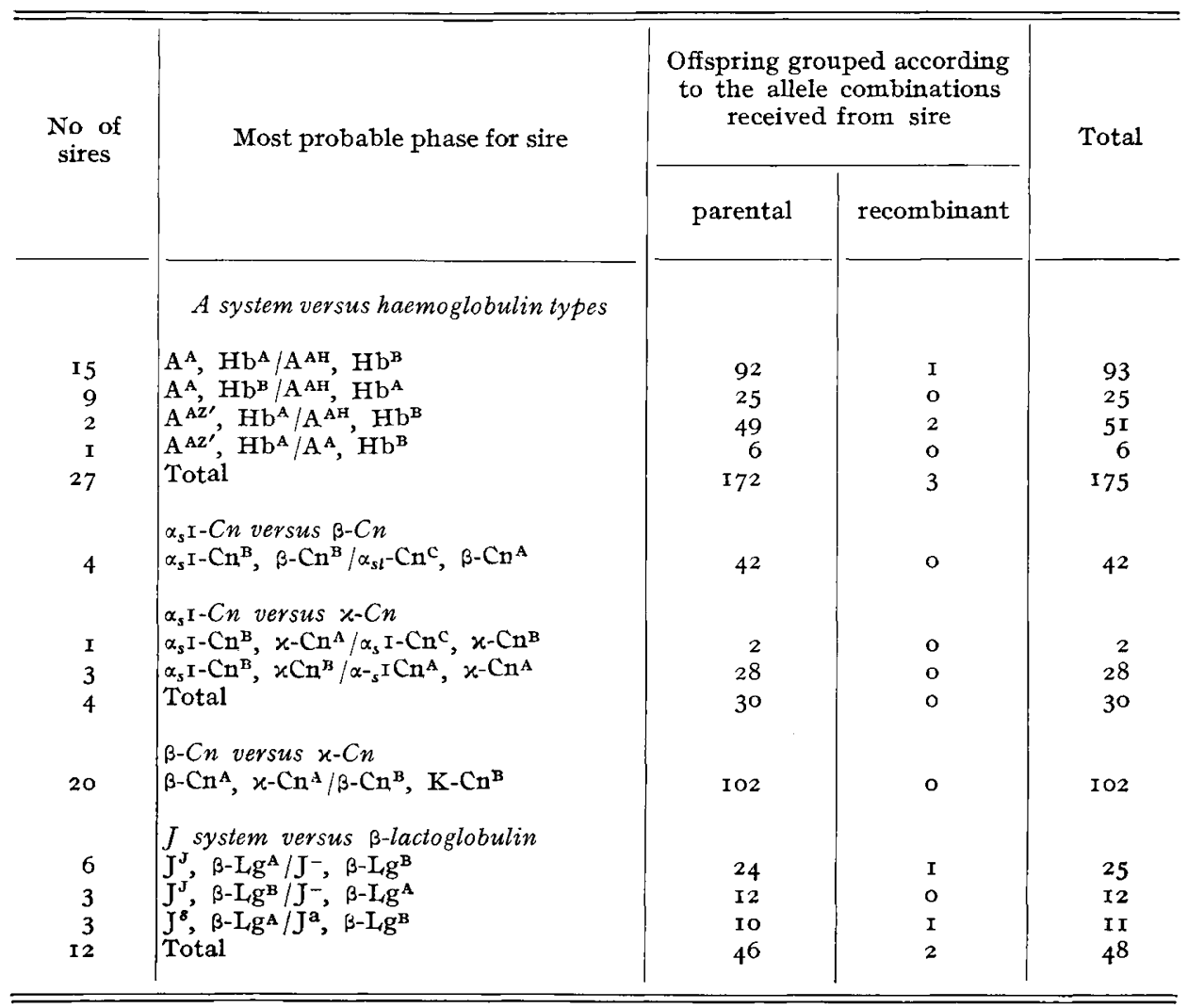


be excluded between the various systems compared. Thus for the comparison of the A system to the $\beta$-lactoglobulin $(\beta-\mathrm{Lg})$, significant evidence was obtained to the effect that these two loci are not located closer to each other on the same chromosome than corresponds to at least 13 per cent of recombination.

For loci where linkage has been disclosed an estimate of the recombination frequency $(\hat{\theta})$ is given in table 3 . In agreement with previous analyses it appears from table 3 that the A blood group system is closely linked to the haemoglobin types, the three casein polymorphisms, $\alpha_{s_{1}}-\mathrm{Cn}, \beta-\mathrm{Cn}$ and $x_{-} \mathrm{Cn}$ form a system of closely linked genes and that the $\mathrm{J}$ blood group system shows a close relationship to the $\beta$-lactoglobulin types.

The families relevant to the study of the linkage groups just mentioned are shown in table 4. In this table the families are grouped according to the most probable phase of the sire. From the table it appears that between the $\mathrm{A}$ and the $\mathrm{Hb}$ systems only 3 possible recombinants are observed out of a total of I75 offspring. In the comparison of the three casein systems only the parental types are found in our data. Also in a study made by GROsclaUdE et al. (I964, I965) only parental types of offspring were found, while HINEs et al. (I969) observed some apparent recombinants in the $\alpha_{s_{1}}-\mathrm{Cn}$ and $\beta$-Cn comparison as well as in the $\alpha_{s} \mathrm{I}$-and $x$-Cn comparison, but not between the $\beta$-Cn and $x$-Cn types. Thus a very close linkage of the genes controlling the casein polymorphisms has been established. The data in table 4 relevant to elucidating the relationship of the $\mathrm{J}$ blood group substance and the $\beta$-lactoglobulin types show about 4 per cent of recombination, while HINEs et al. (I969) in a similar study observed 20 per cent of recombination. Furthermore, in our data a disturbed segregation of the $\beta$-lactoglobulin types in the families relevant to the linkage studies was observed, while the total data showed a perfect I : I segregation of the $\beta$-Lg. This may suggest that the observed relation of the $\beta$ - Lg is not directly to the $\mathrm{J}$ substance or cellular $J$, but to a factor or genetic system related to or influencing the appearance of the $\mathrm{J}$ substance in the plasma and on the red cells. The correct interpretation of this relationship may, therefore, await a better understanding of the genetics underlying the $J$ factor and the closely related Oc substance.

From table 3 it is seen that 25 per cent of recombination can be excluded between the Tf and Am loci. However, a possible but non-significant indication for a loose linkage of these two loci was observed. In the case of linkage being present between the transferrin and amylase loci, the recombination frequency is estimated to be about 37 per cent.

The remainder of the total 149 comparisons indicated in table 3 did not reveal any significant dependency and as a matter of fact moderate to loose linkage has been excluded, indicating that these systems are fairly well distributed on the entire set of autosomes in cattle.

In table 5 the linkage relations of blood groups and biochemical polymorphisms known to-day in farm animals are indicated. Besides linkage relations in cattle just mentioned, four examples of close linkage have been disclosed in pigs. For the $\mathrm{C}$ and $\mathrm{J}$ blood group systems the recombination frequency is estimated to 5.5 per cent (ANDRESEN, I968), and the other three groups show even closer linkage. ANDRESEN (r968) showed to what extent linkage among blood 
group and polymorphic protein loci in pigs can be excluded and presented data indicating a possible but non-significant loose linkage between the B blood group system and the prealbumin system in pigs. In sheep the genetically controlled low $\left(\mathrm{K}^{\mathrm{L}}\right)$ and high $\left(\mathrm{K}^{h}\right)$ potassium level in the red cells is closely related to the $\mathrm{M}$ blood group system. Animals having the dominant gene $\mathrm{K}$ for low potassium content in homozygotous state seem to be negative for the $\mathrm{M}$ factor ( $\left.\mathrm{M}^{-} / \mathrm{M}^{-}\right)$,

TABLE 5

The polymorphic systems showing linkage relations in large farm animals

TABLEAU 5

Relations de linkage entre les systèmes polymorphiques des gros animaux domestiques

\begin{tabular}{|c|c|c|}
\hline Species & Loci & References \\
\hline Cattle & $\begin{array}{l}A \text { and } \mathrm{Hb} \\
\alpha_{s 1}-\mathrm{Cn} \text { and } \beta-\mathrm{Cn} \\
\alpha_{s 1}-\mathrm{Cn} \text { and } x-\mathrm{Cn} \\
\beta-\mathrm{Cn} \text { and } x_{-}-\mathrm{Cn} \\
J \text { and } \beta-I_{1} g\end{array}$ & $\begin{array}{l}\text { LARSEN I } 966 \text {, I969. } \\
\text { GROSCLAUDE } \text { et al. I964, I } 965, \\
\text { THYMANN and LARSEN I } 965, \\
\text { LARSEN and THYMANN I } 966 a \text {, } \\
\text { HINES } \text { et al. I } 969 . \\
\text { LARSEN I } 969, \text { HINES et al. } 1969 .\end{array}$ \\
\hline Swine & $\begin{array}{l}\mathrm{C} \text { and } \mathrm{J} \\
\mathrm{K} \text { and } \mathrm{Hpx} \\
\mathrm{I} \text { and } \mathrm{Am} \\
\mathrm{H} \text { and } 6-\mathrm{PGD}\end{array}$ & $\begin{array}{l}\text { ANDRESEN and BAKER I964, } \\
\text { ANDRESEN I966, I968. } \\
\text { IMLAH I964, NIELSEN I966 } b \text {, } \\
\text { HESSELHOLT and NIELSEN I } 966 \text {, } \\
\text { ANDRESEN I966, I968. } \\
\text { NIELSEN I } 966 a \text {, I966 } b \text {, HESSELHOL' } \text { et al. I966, } \\
\text { ANDRESEN I966, I968. } \\
\text { ANDRESEN I970. }\end{array}$ \\
\hline Sheep & $\begin{array}{l}\text { M and erythro- } \\
\text { cyte potassium } \\
\text { level }\end{array}$ & RASMUSEN and HALI, I966a, I966 $b$. \\
\hline
\end{tabular}

heterozygote $\mathrm{K}^{\mathrm{L}} / \mathrm{K}^{h}$ possibly also is heterozygotous for the $\mathrm{M}$ factor $\left(\mathrm{M}^{\mathrm{M}} / \mathrm{M}^{-}\right.$) and individuals being homozygous for high potassium level $\left(\mathrm{K}^{h} / \mathrm{K}^{h}\right)$ appear to be homozygous for the $M$ blood group factor also $\left(M^{M} / M^{M}\right)$.

So far the search for linkage of monogenetic characters in farm animals has been devoted mainly to studies of the mutual relations of serologically and biochemically detectable marker loci. However the relationship of these marker loci to morphological and pathological characters with known inheritance needs our attention. Such studies are under way and recently IMLAH (I970) presented. evidence for the Tf locus being associated to a lethal factor in a strain of pigs. In cattle Maijala and Lindstrom (r964) investigated the possible linkage of blood group systems to the occurrence of hairless calves in connection with a prolonged gestation period, presumed to be caused by a recessive lethal gene. They found that the lethal was not closely linked to any of the blood group systems studied. With regard to morphological characters we have had an opportunity 
to test a family where a bull of the Danish Black and White dairy cattle, being heterozygous for the black coat colour, was mated to cows of Red Danish dairy cattle breed. From the offspring in this family it could be concluded that the locus controlling the black and red colour in cattle is not closely linked to the $\mathrm{B}$, $\mathrm{M}, \mathrm{R}^{\prime} \mathrm{S}^{\prime}$, Tf, and Am loci.

The results from the linkage studies on blood groups and polymorphic protein loci in cattle and swine show that apart from the linkage relations mentioned in table 4 and the possibility of a Tf-Am relationship in cattle and a B-Pra relation in pigs the loci so far studied in these two animal species are well distributed over the entire number of autosomes. This result alone is important because it suggests that a search for linkage is more likely to be successful whenever additional loci are included. The ultimate objective is a more complete mapping of the chromosomes to which also cytogenetic studies may contribute for the localization of the various loci in the chromosomes. Thus it seems possible that the contribution of immunogenetics and biochemical genetics to animal breeding programs may be extended in the future.

$$
\text { Reçu pour publication en septembre } 1970 .
$$

\section{ACKNOWLEDGMENTS}

The author is greatly indebted to the Head of Department, Professor Dr. med. vet. Johs. Moustgaard and present as well as former colleagues (Drs. E. Andresen, M. Hesselholt, A. Neimann-Sorensen, P. Bräuner Nielsen and M. Thymann) for assistance and helpful discussions.

\section{RÉSUMÉ}

\section{GROUPES SANGUINS ET POLYMORPHISME PROTFINIQUE}

\section{CHEZ LE BEUF ET LE PORC}

Les loci de groupes sanguins et les polymorphismes protéiniques du Bœuf et du Porc mis en évidence au moyen d'études immuno et biochimico-génétiques sont brièvement décrits. L'utilisation de ces systèmes pour le contrôle de la parenté pour l'amélioration génétique (comme loci marqueurs) est discutée.

Sur 10 loci de groupes sanguins et 7 loci de polymorphysme protéinique les études de linkage ont montré chez les Bovins un linkage étroit du locus de groupe sanguin $\mathrm{A}$ avec un locus contrốlant l'hémoglobine. Il y aurait également une très forte liaison entre les loci des caséines $\alpha-81$, $\beta$ - et $x$. Une relation étroite du locus du système $J$ avec le locus de $\beta$-lactoglobuline chez le Bœuf existe aussi sans doute. Il semblerait qu'en outre, une liaison assez lâche entre les loci contrôlant le polymorphisme des transferrines et de la sero-amylase puisse être décelée.

Les groupes de linkage du Porc et du Mouton sont également envisagés en relation avec une future utilisation des gènes marqueurs en sélection animale.

\section{REFERENCES}

ANDRESEN, E., I963. A study of blood groups of the pig. Munksgaard, Copenhagen.

ANDREsEn, E., 1966. Linkage and epistasis exemplified by genetic systems in pigs. Proc. Europ. Anim. Blood Grp. Conf., Paris, 4I5-420.

ANDREsen, E., r968. Sequential analysis of genetic linkage in pigs. Royal Vet. and Agric. University Copenhagen, Yrb., I-II.

ANDRESEN, E., I970. I,inkage between the $\mathrm{H}$ and 6-PGD loci in pigs. Acta vet. scand., 11, I36-I37.

ANDREsEN, E. and L. N. BAKER, I964. The C blood group systems in pigs and the detection and estimation of linkage between the $\mathrm{C}$ and $\mathrm{J}$ systems. Genetics, 49, 379-386. 
Aschaffenburg, R., I968. Reviews of the progress of dairy science. Section G. Genetics. Genetic variants of milk proteins : their breed distribution. J. Dairy Res., 35, 447-460.

BRILES, W. E. and C. P. AllAN, I96r. The B blood group system of chicks. II. The effects of genotype on liveability and egg production in several commercial inbred lines. Genetics, 46, I 273-I294.

BRUM, E. W., W. H. RAUSCh, H. C. Hines and T. U. LuDwick, I968. Association between milk and blood polymorphism types and lactation traits of Holstein cattle. J. Dairy Sci., 51, I03I-I038.

Grosclaude, F., J. Garnier, B. Ribadeau-Dumas et R. Jeunet, r964. Fitroite dependance des loci contrôlant le polymorphisme des caséines $\alpha_{s}$ et $\beta, C . R$. Acad. Sci. (Paris), 259, r569-r 57r.

Grosclaude, F., J. Pujolle, J. Garnier et B. Ribadeau-Dumas, 1965. Déterminisme génétique des caséines $x \mathrm{du}$ lait de vache; étroite liaison du locus $x$-Cn avec les loci $\alpha_{8}$-Cn et $\beta-\mathrm{Cn}$. C. R. Acad. Sci. (Paris), 261, 5229-5232.

Gordon, W. G., J. J. BASCH and E. B. KaLAN, I96r. Amino acid composition of $\beta$-lactoglobulins A, B and AB. J. Biol. Chem., 236, 2908-291r.

HeSSElHOLT, M., 1969. Serum protein polymorphisms in swine. Munksgaard, Copenhagen.

Hfsselholt, M. and P. B. Nielsen, I966. Studies on the genetic relationship between the haemopexin system and other blood group systems in pigs. Proc. Europ. Anim. Blood Grp. Conf., Paris, 445-447.

Hesselfolt, M., B. LARSEN and P. B. Nielsen, r966. Studies on serum amylase systems in swine, horses and cattle. Royal Vet. and Agric. University, Copenhagen, Yearbook, 78-9o.

HINES, H. C., C. A. KIDDY, E. W. BRuM and C. W. ARAwE, rg69. Linkage among cattle blood and milk polymorphisms. Genetics, 62, 40I-4I2.

Hojný, J., M. Gavalier, J. Hradecký and J. I,INDhart, 1966. New blood factors in pigs. Proc. Europ. Anim. Blood Grp. Cont., Paris, 15I-158.

Hojný, J. and J. HRadecký, 1968. Dextran test in the study of blood groups in pigs. Proc. Europ. Anim. Blood Grp. Cont. Warsaw, 259-264.

Huisman, T. H., 1966. Hemoglobin types in some domestic animals. Proc. Europ. Anim. Blood Grp. Cont., Paris, 6r-75.

ImLAH, P., 1964. A study of blood groups in pigs. Proc. Europ. Anim. Blood Grp. Conf., Prague, ro9-122.

IMLAH, P., I970. Evidence for the $\mathrm{Tf}$ locus being associated with an early lethal factor in a strain of pigs. Anim. Blood Grp. biochem. Genet., 1, 5-13.

Jamieson, A. and A. Robertson, 1967. Cattle transferrin and milk production. Anim. Prod., 9, 49x-500.

JENSEN, E. I., C. SMrth, I. N. BAKER, and D. F. Cox, r968. Quantitative studies on blood group and serum protein systems in pigs. II. Effects on production and reproduction. J. Anim. Sci., 27, 856-862.

LARSEN, B., 1966. Test for linkage of the genes controlling haemoglobin, transferrin and blood types in cattle. Royal and Vet. Agric. University, Copenhagen, Yrb., 4I-48.

LARSEN, B., 1969. On linkage relation of blood groups in cattle. (In Danish, English summary.) Aarsberetn. Inst. Sterilitetsforsk., Copenhagen, $3 \mathrm{r}-38$.

LARSEN, B., I970. Linkage relations of blood group and polymorphic protein systems in cattle. (In Danish, English summary.) Aarsberetn. Inst. Sterilitetsforsk., Copenhagen, 165-194..

IAARSEN, B. and MARIANN THYMAN, 1966. Studies on milk protein polymorphism in Danish cattle and the interaction of the controlling genes. Acta vet. scand., 7, I89-205.

MAIJALA, K. and G. LINDSTROM, I964. On the relation between blood group genes and a lethal gene for hairlessness and prolonged gestation. Proc. Europ. Anim. Blood Grp. Conf., Prague, 46I-462.

MITSChERLICh, E., A. Tolle and W. Walter, r959. Untersuchungen über das Bestehen von Beziehungen zwischen Blutgruppenfaktoren und der Milchleistung des Rindes. Z. Tierz. Züchtbiol., 72, 289-301.

NEIMANN-SORENSEN, A., 1959. Blood groups of cattle. C. Fr. Mortensen, Copenhagen.

NeImANn-Sorensen, A. and A. Rober'Tson, I96r. The association between blood groups and several production characteristics in three Danish cattle breeds. Acta agric. scand., 11, I63-196.

Nrelsen, P. B., I966a. Studies on the genetic relationship between the serum amylase system and other blood group systems in pigs. Proc. Europ. Anim. Blood Grp. Conf., Paris 449-452.

Nrelsen, P. B., I 966 b. Studies on the genetic relationship between the serum type-and blood group systems in pigs. (In Danish, English summary.) Aarsberetn. Inst. Sterilitetsforsk., Copenhagen, 65-74.

Piez, K. A., F.. W. Davie, J. E. Folk and J. A. Gladner, I96r. B-lactoglobulins A and B. I. Chromatographic separation and amino acid composition. J. biol. Chem., 236, 291 2-29x6.

RASMUSEN, B. A. and J. G. HALI, r966a. An investigation into the association between potassium levels and blood types in sheep and goats. Proc. Europ. Anim. Blood Grp. Cont., Paris, 453-457.

RASmUSEn, B. A. and J. G. HALL, 1966 b. Association between potassium concentration and serological type of sheep red blood cells. Science, 151, I55I-I 552.

RENDEL, J., r96r. Relationship between blood groups and the fat percentage of the milk in cattle. Nature, 189, 408-409.

SMrTH, C., I967. Improvement of metric traits through specific genetic loci. Anim. Prod., 9, 349-358.

SMmThIES, O., I955. Zone electrophoresis in starch gels: Group variations in the serum proteins of normal human adults. Biochem. J., 61, 629-64I.

SPRAGUE, L. M., 1958. On the recognition and inheritance of the soluble blood group property "Oc" of cattle. Genetics, 43, 906-912.

SToRmont, C., r95I. An example of a recessive blood group in sheep. Genetics, 36, 577-578.

Stormont, C., I962. Current status of blood groups in cattle. Ann. N.Y. Acad. Sci., 97, 251-268.

THYMANN, MARIANN and B. LARSEN, 1965. Milk protein polymorphism in Danish cattle. (In Danish, English summary.) Aarsberetn. Inst. Sterilitetsforsk., Copenhagen, 225-250. 